\title{
ARTICLES
}

\section{Modeled Gravitational Unloading Triggers Differentiation and Apoptosis in Preosteoclastic Cells}

\author{
Monica Monici, ${ }^{1 *}$ Franco Fusi, ${ }^{2}$ Milena Paglierani, ${ }^{3}$ Nicola Marziliano, ${ }^{4}$ Augusto Cogoli, ${ }^{5}$ \\ Riccardo Pratesi, ${ }^{6}$ and Pietro Antonio Bernabei ${ }^{7}$ \\ ${ }^{1} \mathrm{CEO}$-Center of Excellence in Optronics, L. Enrico Fermi 6, I-50125 Florence, Italy \\ ${ }^{2}$ Department of Clinical Physiopathology, University of Florence, V.le Pieraccini 6, I-50139 Florence, Italy \\ ${ }^{3}$ Department of Human Pathology and Oncology, Careggi Hospital, V.le Morgagni 45, \\ I-50134 Florence, Italy \\ ${ }^{4}$ IRCCF, San Matteo Hospital, Piazzale Golgi 2, I-27100, Pavia, Italy \\ ${ }^{5}$ Zero-g LifeTec GmbH, ETH-Technopark, Technoparkstr. 1, CH-8005, Zurich, Switzerland \\ ${ }^{6}$ Department of Physics, University of Florence, Via Sansone 1, I-50019 Sesto Fior., Florence, Italy \\ ${ }^{7}$ Hematology Division, Careggi Hospital, V.le Morgagni 45, I-50134, Florence, Italy
}

\begin{abstract}
Gravity acts permanently on organisms as either static or dynamic stimulation. Understanding the influence of gravitational and mechanical stimuli on biological systems is an intriguing scientific problem. More than two decades of life science studies in low g, either real or modeled by clinostats, as well as experimentation with devices simulating different types of controlled mechanical stimuli, have shown that important biological functions are altered at the single cell level. Here, we show that the human leukemic line FLG 29.1, characterized as an osteoclastic precursor model, is directly sensitive to gravitational unloading, modeled by a random positioning machine (RPM). The phenotypic expression of cytoskeletal proteins, osteoclastic markers, and factors regulating apoptosis was investigated using histochemical and immunohistochemical methods, while the expression of the corresponding genes was analyzed using RT-PCR. A quantitative bone resorption assay was performed. Autofluorescence spectroscopy and imaging were applied to gain information on cell metabolism. The results show that modeled hypogravity may trigger both differentiation and apoptosis in FLG 29.1 cells. Indeed, when comparing RPM versus $1 \times$ g cultures, in the former we found cytoskeletal alterations and a marked increase in apoptosis, but the surviving cells showed an osteoclastic-like morphology, overexpression of osteoclastic markers and the ability to resorb bone. In particular, the overexpression of both RANK and its ligand RANKL, maintained even after return to $1 \times \mathrm{g}$ conditions, is consistent with the firing of a differentiation process via a paracrine/autocrine mechanism. J. Cell. Biochem. 98: 65-80, 2006. (c) 2005 Wiley-Liss, Inc.
\end{abstract}

Key words: weightlessness; preosteoclastic differentiation; apoptosis; bone resorption; osteoporosis; gene expression

The importance of gravity in modulating some biological processes, such as plant gravitropism and the adaptation of the vertebrate skeleton in relation to its load-bearing function, has long been known. Nevertheless, the role of gravity and other mechanical factors in biological processes is far from clear. A weightless environment is a powerful tool for

Grant sponsor: ASI-The Italian Space Agency.

*Correspondence to: Dr. Monica Monici, Consorzio CEOCentro di Eccellenza Optronica, Largo Enrico Fermi, 6 I50125, Florence, Italy. E-mail: monici@ino.it

Received 5 July 2005; Accepted 24 October 2005

DOI 10.1002/jcb.20747

(c) 2005 Wiley-Liss, Inc. understanding this role and for studying the related cellular and molecular mechanisms. Several investigations conducted in space laboratories and with instruments averaging the gravity vector, and thus simulating conditions of reduced gravity, have shown that isolated cells may change their behavior under altered gravitational conditions. Loss of cell activation [Cogoli et al., 1984], perturbation of signal transduction [Schmitt et al., 1996; Hashemi et al., 1999] and modification of genetic expression [Walther et al., 1998; Hammond et al., 1999] have been described. This suggests that some of the mechanisms at the roots of the systemic effects observed in weightlessness, such as depression of the immune system [Gmünder and Cogoli, 1996] 
and reduction in bone mass [Morey-Holton et al., 1996], can originate at the cellular level.

The systematic study of cellular response to mechanical stimuli other than gravitational force [Brown, 2000] has proved that mechanical input affects cell behavior. For example, endothelial cells can be switched among the three major genetic programs that govern angiogenesis, growth, apoptosis, and differentiation, by alteration of cell spreading on micropatterned substrates [Dike et al., 1999].

Bone homeostasis is particularly sensitive to both gravitational and mechanical stimuli, which play a very important role in determining bone structure and influencing related metabolic and catabolic processes [Frost, 1988]. Bone turnover depends on the balance of bone formation by osteoblasts and bone resorption by osteoclasts. The gravitational unloading on the skeleton, due either to space flight missions or to immobilization, causes an imbalance between bone formation and resorption, leading to osteoporosis. It has been demonstrated that this bone loss may be derived from a decrease in osteoblastic activity as well as from an increase in osteoclastic activity [Carmeliet et al., 2001].

In vitro studies have provided evidence that bone cells, both osteoblasts [Roclofsen et al., 1995; Stanford et al., 1995; Nagatomi et al., 2001] and osteoclasts [Rubin et al., 1999; McAllister et al., 2000; Kurata et al., 2001], directly respond to various kinds of mechanical stimuli. With regard to the effect of gravitational unloading, the studies have mainly focused on osteoblasts [Hughes-Fulford et al., 1998; Sarkar et al., 2000; Bikle et al., 2003; Ontiveros and McCabe, 2003], while few reports deal with the behavior of osteoclastic cells and their precursors. Osteoclasts are cells of hemopoietic origin that, through a differentiation process, assume the ability to resorb bone [Suda et al., 1992].

In space flight experiments, histomorphological investigations on skeletal tissues showed an increased number of osteoclastic cells [Kaplansky et al., 1991; Vico et al., 1993]. Enhancement of osteoclastic mineral resorption (measured as the release of ${ }^{45} \mathrm{Ca}$ from prelabeled bone) was observed as well [Van Loon et al., 1995]. Recently, it was shown that the gene expression of the receptor activator of NF$\kappa \mathrm{B}$ ligand (RANKL) and osteoprotegerin, two molecular species of critical importance for osteoclastogenesis regulation, is altered in cells from the mouse stromal cell line ST2 placed in modeled hypogravity conditions [Kanematsu et al., 2002].

The aim of the present work was to determine whether vector averaged gravity has a direct effect on osteoclastic precursor cells and, in particular, on their ability to undertake a differentiation process, thus addressing the hypothesis that a hypogravity-induced increase in preosteoclastic differentiation could be among the mechanisms responsible for the bone loss observed in weightlessness.

The findings demonstrated that culturing in gravitational unloading, modeled in a random positioning machine (RPM), strongly affected the behavior of the human bone marrowderived FLG 29.1 cells, used as an experimental model.

\section{MATERIALS AND METHODS}

\section{Cell Line}

The cell line FLG 29.1, derived and stabilized from a culture of bone marrow cells collected from a patient affected with acute monoblastic leukemia (FAB: M5a), was previously characterized as a model of osteoclastic precursor [Gattei et al., 1992].

The cells were maintained in RPMI 1640 medium (Sigma-Aldrich, Germany), supplemented with $10 \%$ heat-inactivated fetal calf serum, $300 \mu \mathrm{g} / \mathrm{ml}$ L-glutamine, $50 \mu \mathrm{g} / \mathrm{ml}$ gentamicin, and split twice a week. The cultures were carried out in a fully humidified atmosphere, at $37^{\circ} \mathrm{C}$ and $5 \% \quad \mathrm{CO}_{2}$. Viability was determined using the blue trypan dye exclusion assay.

For experiments in modeled hypogravity, cells were transferred to vials filled with fresh culture medium and containing bone slices. The vials were specifically designed for use in experiments under both real and modeled weightlessness by the Space Biology Group from ETH Zurich [Cogoli et al., 1988]. In brief, each chamber consisted of a cylinder $(11 \mathrm{~mm}$ in diameter and $2 \mathrm{~cm}$ in height) carved in Erta Peek $\odot$ blocks $(10 \times 5 \times 2 \mathrm{~cm})$. The chambers were sealed top and bottom by two mobile pistons. One of the pistons carried a septum to facilitate the injection of chemicals when needed. Control samples were prepared in the same type of vials and in fully comparable experimental conditions, with the exception of gravity $(1 \times \mathrm{g})$. 
The $\mathrm{pH}$ value, measured in the culture medium before and after the experiment, remained constant.

A stabilized human cell line was preferred as an experimental model because of the several advantages offered compared to cells in primary culture. The homogeneity of the biological material allows for better standardization of the experimental conditions and ensures repeatability and reproducibility without limits of time. Moreover, it offers the possibility of obtaining large amounts of cells and of confirming experimental observations in different laboratories under comparable conditions.

\section{Random Positioning Machine}

Low g conditions were modeled in a RPM (Dutch Space, formerly Fokker Space, Leiden, The Netherlands). In the RPM, introduced by Hoson et al. [1997], probes are fixed as close as possible to the center of two frames rotating one inside the other, driven by separate motors. The rotation of each frame is random and autonomous under computer control. A software program drives the motors in a smooth, continuous (i.e., joltless) movement. The angular velocity of rotation can be selected between $30^{\circ}$ and $360 \%$ s. The low $g$ conditions are modeled by averaging the gravity vector via the independent rotation of the two frames.

In the experiments described here, the angular velocity of rotation was $60^{\circ} \mathrm{s}$. Temperature was maintained at $37^{\circ} \mathrm{C}$. The treatment lasted for $72 \mathrm{~h}$. Control samples $(1 \times \mathrm{g})$ were placed on the fixed base of the RPM, facing the same vibrations as the rotating ones.

At the end of the treatment, the cells were recovered and prepared for cytochemical and immunocytochemical assays or lysed for RTPCR, or re-cultured at $1 \times \mathrm{g}$. Bone slices were sonicated when the removal of adherent cells was required, then prepared for analysis by Surface Profilometry and Scanning Electron Microscopy.

\section{Annexin-V-FLUOS Assay}

For the detection and quantification of apoptosis and discrimination from necrosis at a single cell level, we used the Annexin-V-FLUOS Staining Kit (Roche Diagnostics, Germany). The cells $\left(1 \times 10^{6}\right)$ were washed in Dulbecco's phosphate buffered saline (Sigma-Aldrich, Germany), centrifuged at $200 \mathrm{~g}$ for $5 \mathrm{~min}$, then resuspended in $100 \mu$ l Annexin-V-Fluorescein in HEPES buffer containing propidium iodide (Sigma-Aldrich, Germany) and incubated at $15-25^{\circ} \mathrm{C}$ for $15 \mathrm{~min}$.

The samples were analyzed by a FACScan flow cytometer (Becton Dickinson San Jose, CA) using $488 \mathrm{~nm}$ excitation and Cell Quest software (Becton Dickinson).

\section{Histochemical and Immunohistochemical Methods}

Reagents for routine staining of cells (hematoxylin-eosin and Giemsa) were from Merck KgaA, Darmstadt, Germany.

Samples from the RPM and the controls (cell density $10^{6} / \mathrm{ml}$ ) were diluted 1:20 with CytoRich Blue Preservative Fluid. An Autocyte PREP System (Autocyte, Inc., Burlington, NC) was utilized to prepare cell monolayers of a $13 \mathrm{~mm}$ diameter, subsequently air-dried at room temperature for $2 \mathrm{~h}$. The May-Grünwald Giemsa staining and Tartrate-Resistant Acid Phosphatase (TRAP) (the substrate Naphtol As-Bi Phosphate was from Sigma-Aldrich Corporation, St. Louis, MO) assays were performed. The expression of $\alpha \mathrm{v} \beta 3$, RANK, RANKL, $\alpha$-actin, F-actin, $\alpha$-tubulin, vimentin, p53, Fas, FasL, Bax, and Bcl-2 was assayed by immunocytochemical staining; cell monolayers were incubated with the specific anti-human antibodies $\alpha \mathrm{v} \beta 3$ (clone LM609, Chemicon International, Temecula, CA), RANK (rabbit polyclonal, Santa Cruz Biotechnology, Santa Cruz, CA), RANKL (FL-317, sc-9073, Santa Cruz Biotechnology, Santa Cruz, CA), $\alpha$-actin (clone 1A4, Sigma Chemical Co, St. Louis, MO), Factin (clone NH3, Ab cam Limited, Cambridge, UK), $\alpha$-tubulin (clone DM1A, Neomarkers, Fremont, CA), vimentin (clone V9, BioGenex, San Ramon, CA), p53 (clone DO-7, DakoCytomation Denmark A/S, Glostrup, DK), Fas and FasL (clone GM30 and 5D1, respectively, Novocastra Laboratories, Ltd., Newcastle, UK), Bax (polyclonal, Dako Carpenteria), and Bcl-2 (clone 124, DakoCytomation Denmark A/ S, Glostrup, DK).

Immunostaining was performed using a streptavidin-biotin peroxidase system kit (Lab Vision Corporation, Fremont, CA). The slides were developed with $3,3^{\prime}$-diaminobenzidine (DAB, BioGenex), and the nuclei were counterstained with Mayer's hematoxylin. A negative control was carried out by replacing the primary antibody with non-immune mouse 
serum. Sections of human osteosarcoma were used as the positive control. The monolayers were examined by light microscopy with a $100 \times$ immersion oil objective.

\section{Multispectral Imaging Autofluorescence Microscopy and Autofluorescence Microspectroscopy}

Cells contain molecules, like pyridinic coenzymes $(\mathrm{NAD}(\mathrm{P}) \mathrm{H})$ and flavins that become fluorescent when excited by UV-vis radiation of a suitable wavelength. This fluorescence emission, called autofluorescence (AF) because it arises from endogenous fluorophores, is an intrinsic cell parameter. AF monitoring and analysis provide information on cell morphology as well as on cellular energy metabolism [Chance, 1989; Fusi et al., 2002].

Here, cell AF analysis was performed using an inverted epifluorescence microscope (Nikon Eclipse TE 2000 E) equipped with an oilimmersion CF-UV flor $100 \times$ objective (N.A. 1.3), under $365 \mathrm{~nm}$ excitation from a filtered (10 $\mathrm{nm}$ bandwidth interference filter, 365FS1025, Andover), high-pressure mercury lamp (HBO $100 \mathrm{~W}$, Osram). The $365 \mathrm{~nm}$ wavelength is particularly suitable for $\mathrm{NAD}(\mathrm{P}) \mathrm{H}$, but able to excite flavins and lipopigments too [Andersson et al., 1998]. In this way, the most important endogenous fluorophores emitting in the visible range were detected at the same time. The fluorescence signal, transmitted through a dichroic mirror at $400 \mathrm{~nm}$ (DM400, Nikon) was detected, according to the position of a mobile mirror, by a diode-array spectrophotometer (based on an ARC polychromator equipped with a Hires III cooled digital CCD camera (DTA, Italy) and a back illuminated SITe $330 \times 1,100$ pixels sensor through an optical fiber bundle ( $1 \mathrm{~mm}$ diameter), or by a Hires III digital CCD camera (DTA, Italy) equipped with a Kodak KAF261E, $512 \times 512$ pixels, detector. Hence, the system allowed for sequential measurements of spectra and images on the same cell. A motorized filter wheel, which can hold up to eight different interference filters, was placed in front of the CCD detector for imaging. It allowed for multispectral sequential acquisition under software controlled by the host computer. The choice of the filter series was made on the basis of the main spectral bands determined by preliminary analysis of the $\mathrm{AF}$ spectra.

\section{Bone Resorption Assay}

Advanced surface techniques to inspect bone surface have been proposed [Moss et al., 1989; Walsh et al., 1991; Schwartz et al., 2000]. We applied a new method based on surface profilometry and imaging [Fusi et al., 2005]. Bone resorption was evaluated by using a mechanical profilometer (Hammelwerke T 2000, vertical resolution $0.1 \mu \mathrm{m}$, diamond point $5 \mu \mathrm{m}$ ). Surface profilometry on suitably finished bovine cortical bone slices, $4 \times 10 \mathrm{~mm}$ and $2 \mathrm{~mm}$ thick, was performed before and after exposure to FLG 29.1 cells in both modeled low $\mathrm{g}$ and $1 \times \mathrm{g}$ conditions. The slice surfaces were prepared and polished with emery to obtain a uniform and low roughness number. On the surfaces of the slices, two perpendicular ruts (width $\cong 200 \mu \mathrm{m}$ and depth $\cong 100 \mu \mathrm{m}$ ) were made with the double function of gathering the cells, thus circumscribing the resorption activity, and providing a geometrical reference for the measurements. Ten roughness profiles $(1,500 \mu \mathrm{m}$ length $)$ spaced at $500 \pm 5 \mu \mathrm{m}$ were acquired for each slice. Consequently, the analyzed surface was about $7,000 \mu \mathrm{m}^{2}$.

Microscopic images of the slices were also acquired. A grazing illumination, obtained by means of a dedicated apparatus, was needed in order to evaluate the roughness of the surface by imaging. A holder for suitably positioning a bone slice and an optical fiber was developed and installed on the microscope.

Both the surface profilometry and the microscopic imaging of the slices, before and after their exposure to FLG 29.1 cells, were repeated at least three times on each slice.

This method, set up in our laboratory, was preferred to other currently used assays because it has the advantage of allowing a direct quantitative determination of the resorbed bone by comparison of surface profiles monitored on the same bone area before and after exposure to the cells [Fusi et al., 2005].

For the scanning electron microscopy (SEM) analysis, carried out using a scanning electron microscope (XL20, Philips, The Netherlands) at a $10 \mathrm{kV}$ accelerating voltage, the specimens were fixed in absolute ethanol and dried at room temperature for $24 \mathrm{~h}$. Subsequently, they were set on aluminum stubs and sputter-coated with a thin film of gold, using an automatic sputter coater (BAL-TEC SCD 050, Balzers, Germany). 


\section{Total RNA Extraction}

FLG 29.1 cells were resuspended in $0.5 \mathrm{ml}$ of $2 \times$ lysis buffer (Applied Biosystems, CA) and then immediately frozen. Total RNA extraction was made by using the ABI PRISM ${ }^{\circledR} 6100$ platform according to the manufacturer's instructions. After extraction, the RNA was resuspended in a final volume of $100 \mu \mathrm{l}$ of elution buffer for spectrophotometric yield quantitation. The average amount was $80 \pm 5 \mathrm{ng} / \mu \mathrm{l}$.

\section{Reverse Transcription}

The total RNA (100 ng) was reverse transcribed using a high-capacity cDNA Archive Kit (Applied Biosystems), random hexamer primers, and the following thermal profile: $25^{\circ} \mathrm{C}$ for $10 \mathrm{~min}, 42^{\circ} \mathrm{C}$ for $1 \mathrm{~h}$, and $95^{\circ} \mathrm{C}$ for $5 \mathrm{~min}$. For all of the further analyses, the cDNA was diluted 1:20 in water.

\section{Quantitative PCR for Gene Expression}

For each of the screened genes, we made use of the Assay on Demand ${ }^{\text {TM }}$ FAM $^{\text {TM }}$ MGBlabeled probes (Table I). We used the GAPDH reference gene $\left(\mathrm{VIC}^{\mathrm{TM}} \mathrm{MGB}-\right.$ labeled probe; PN4319413E), to normalize the different amounts of total RNA in the different wells and their RT reaction efficiencies. RT-PCR was performed using the automated ABI Prism ${ }^{\mathrm{TM}}$ 7900HT Sequence Detector System (Applied Biosystems). The cDNAs were also tested for gDNA contamination, whose overall level was no higher than $0.005 \%$.

\section{Threshold Cycle and the Comparative Method}

Differentially expressed genes were quantitated using the threshold cycle $\left(\mathrm{C}_{\mathrm{t}}\right)$ and the

TABLE I. List of the Assays on Demand ${ }^{\text {TM }}$ IDs Used in this Study

\begin{tabular}{lc}
\hline Gene name & Assay on Demand ${ }^{\mathrm{TM}}$ ID \\
\hline Vimentin & Hs00185584_m1 \\
Tubulin & Hs00744842_sH \\
Alpha-actin & Hs00559403_m1 \\
F-actin & Hs00264539_s1 \\
TRAP & Hs00264539_s1 \\
AlfaVbeta3 & Hs00233790_m1 \\
RANK & Hs00187189_m1 \\
RANKL & Hs00243519_m1 \\
Bax & Hs00180269_m1 \\
Fas & Hs00169544_m1 \\
FasL & Hs00181225_m1 \\
p53 & Hs00364137_m1 \\
Bcl-2 & Hs00418289_m1
\end{tabular}

See the Web site http://myscience.appliedbiosystems.com/navigation/mysciMain.jsp to gather information on the TaqMan ${ }^{\mathrm{TM}}$ probes and primers position for each amplicon. comparative method $\left(2^{-\Delta \Delta \mathrm{Ct}}\right) \quad[$ Livak and Schmittgenb, 2001]. Here, we report an example in Figure 1: (A) Shows the amplification plot of F-actin: from left to right, lines 1, 2, and 3 are the amplification plots of $1 \times \mathrm{g}$, calibrator sample, and RPM specimens, respectively, and their related $\mathrm{C}_{\mathrm{ts}}$ values are $15,18.56$, and 23.45 . (B) Shows the housekeeping gene (GAPDH) amplification plots for the same samples: their $\mathrm{C}_{\mathrm{ts}}$ values are 6. (C) Shows the computational
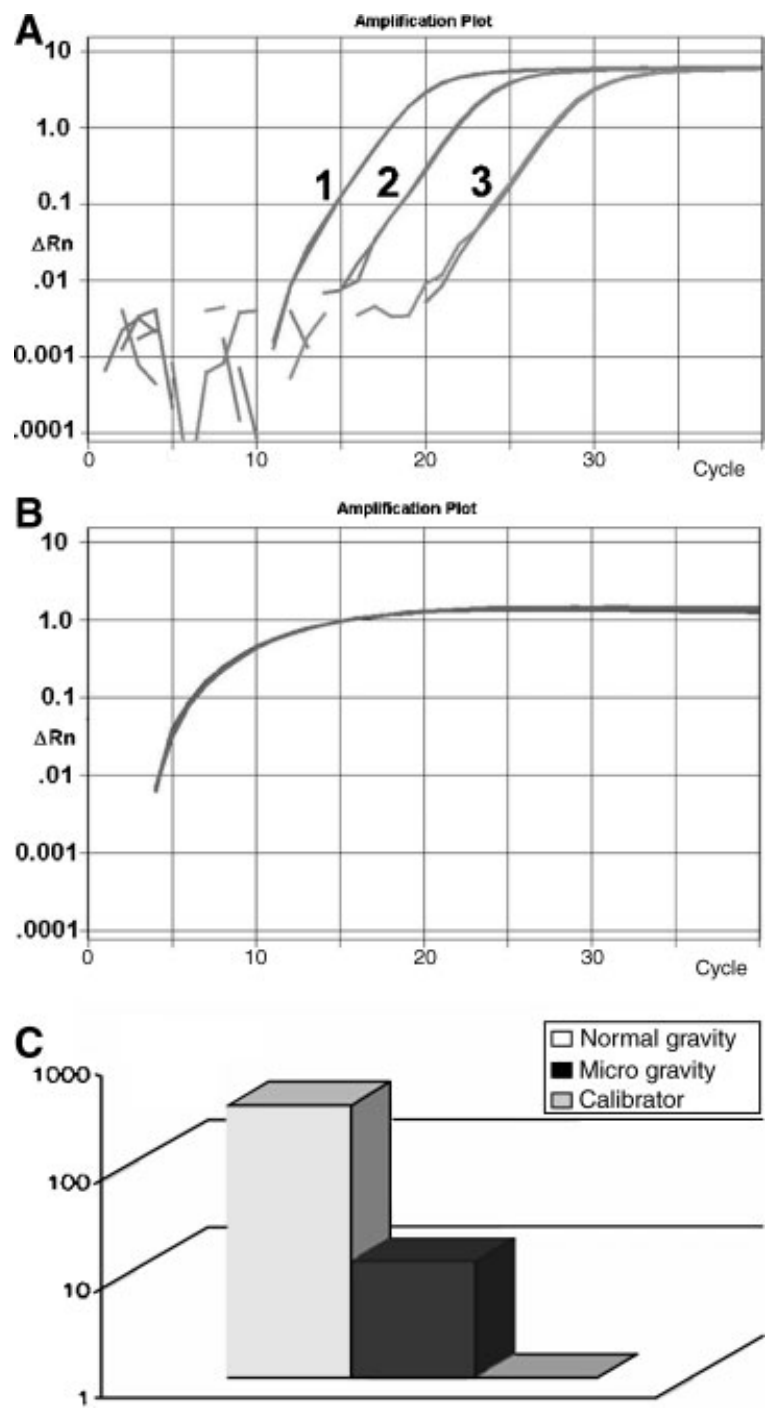

Fig. 1. Comparative $C_{t}$ method (see "Materials and Methods" for computational details). (A) and (B) show examples of amplification plots, with the X-axes indicating the PCR amplification cycles (from 0 to 40 ) and the $y$-axes the fluorescence recorded at each cycle (Rn or Reporter normalized). A: shows the amplification plot of $\mathrm{F}$-actin: from left to right, lines 1, 2, and 3 are the amplification plots of $1 \times \mathrm{g}$, calibrator sample and RPM specimens, respectively; (B) shows the housekeeping gene $(G A P D H)$ amplification plots for the same samples. C: shows the computational results of the comparative $C_{t}$ method. 
results of the comparative $\Delta \Delta \mathrm{C}_{\mathrm{t}}$ method. $\Delta \mathrm{C}_{\mathrm{t}}$ is the difference between the target gene $\mathrm{C}_{\mathrm{t}}(\mathrm{F}$ actin) and the reference gene $\mathrm{C}_{\mathrm{t}}(G A P D H)$ of a given sample, and $\Delta \Delta \mathrm{C}_{\mathrm{t}}$ is the $\Delta \mathrm{C}_{\mathrm{t}}$ of a given sample $(1 \times \mathrm{g}$ or $\mathrm{RPM})$ minus the $\Delta \mathrm{C}_{\mathrm{t}}$ of the calibrator sample (fibroblast cDNA). Thus, $\Delta \mathrm{C}_{\mathrm{t}}$ is 9 (15-6) for the $1 \times \mathrm{g}$ sample, 12.56 (18.56-6) for the RPM sample, and 17.45 (23.45-6) for the calibrator sample. The formula $2^{-\Delta \Delta \mathrm{Ct}}$ (for further details see User Bulletin \#2, www.aplliedbiosystems.com) makes it possible to quantify expression of the $F$-actin gene in the $1 \times \mathrm{g}$ and RPM specimens with the fibroblast cDNA as the calibrator sample. The $\Delta \Delta \mathrm{C}_{\mathrm{t}}$ value is -8.45 for the $1 \times \mathrm{g}$ sample, -3.56 for the RPM sample, and 0 for the calibrator sample, and the related $2^{-\Delta \Delta \mathrm{Ct}}$ values are 341,12 , and 1 , respectively.

\section{Data Analysis}

Three different experiments were carried out in triplicate. For cytochemistry and immunocytochemistry, at least 100 cells per slide were scored and the data were expressed as mean \pm SD. Statistical significance was determined using a Student's $t$ test. A $P$ value lower than 0.05 was considered statistically significant.

For gene expression data analysis, samples from the RPM and the controls were compared by means of 1-way ANOVA, followed by the Duncan multiple-range test. $P$ values of less than 0.001 were considered statistically significant. The $\sigma$ values of every target gene in each gene panel between the RPM and the control groups (which were always less than $0.05 \%$ ) support the reliability of the generated data. In order to assess the reproducibility of the method, we calculated the coefficient of variation for each gene, which was never more than $0.67 \%$.

Autofluorescence spectra were calculated as an average from at least 10 different cells.

\section{RESULTS}

When compared to the $1 \times \mathrm{g}$ control, FLG 29.1 cells cultured for $72 \mathrm{~h}$ in the RPM showed impressive changes in both morphology and function, supported by alterations in both protein and gene expression.

The density of cell population was $1.6 \times$ $10^{5}$ cell $\mathrm{s} / \mathrm{ml}$ in the RPM-exposed samples and $3.6 \times 10^{5}$ cells $/ \mathrm{ml}$ in the controls.

\section{Morphology}

Osteoclastic maturation is defined morphologically as the appearance of large dimension, plurinucleated cells [Suda et al., 1992]. MayGrünwald Giemsa staining of cells exposed to modeled weightlessness showed an increase in large, bi- or pluri-nucleated cells up to $51.3 \pm$ $6.1 \%$, compared to $2.2 \pm 1.5 \%$ of the control at $1 \times \mathrm{g}$ (Fig. 2).

Numerous cells showing typical alterations of apoptosis (shrinkage, membrane blebbing, loss of nuclear envelope, etc.) were also observed. Cytofluorimetric determination using the Annexin-V assay allowed us to quantify the percentage of apoptotic cells after $72 \mathrm{~h}$ culturing in the RPM $(39.4 \pm 3.4 \%)$ compared to the control at $1 \times \mathrm{g}(6.3 \pm 1.1 \%)$.

\section{Cytoskeleton}

It is a common opinion that the cytoskeleton plays a role in mechanotransduction [Ingber, 1997] and gravisensing [Hughes-Fulford, 2003]. Moreover, it has been reported that gravity triggers the self-organization of cytoskeleton microtubules [Papaseit et al., 2000].

In order to ascertain whether random gravity affects cytoskeleton organization in FLG 29.1 cells, we analyzed, using immunocytochemistry, the expression of proteins (vimentin,

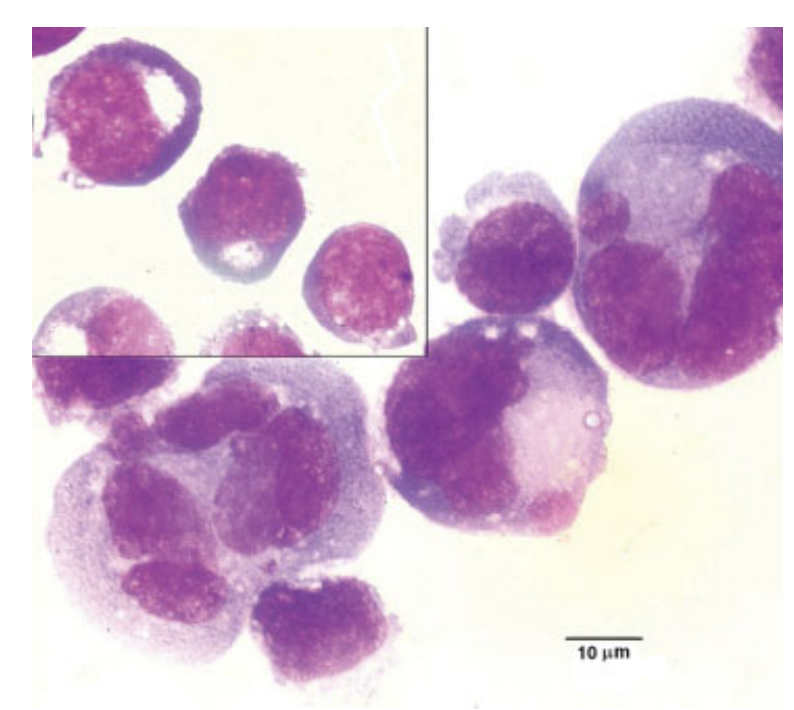

Fig. 2. Morphological appearance of preosteoclastic maturation after $72 \mathrm{~h}$ exposure of FLG 29.1 cells to gravitational unloading modeled in an RPM. The $1 \times \mathrm{g}$ control is shown in the inset. May-Grünwald Giemsa staining. [Color figure can be viewed in the online issue, which is available at www. interscience.wiley.com.] 
$\alpha$-tubulin, $\alpha$ - and F-actin) involved in the building of the cytoskeletal network. As shown in Figure 3A, vimentin expression increased significantly in modeled hypogravity compared to the $1 \times \mathrm{g}$ control $(81.1 \pm 9.7 \%$ vs. $40.7 \pm 7.9 \%$ positivity). On the contrary, $\alpha$-tubulin, $\alpha$-actin, and F-actin, widely expressed in control cells, decreased by about $80 \%, 90 \%$, and $77 \%$, respectively, in cells cultured in the RPM $(P<0.001)$.

The expression of the genes involved in the synthesis of the considered cytoskeletal components was screened by means of a $5^{\prime}$ Nuclease Assay, namely the TaqMan ${ }^{\mathrm{TM}}$ PCR or RealTime PCR [Livak and Schmittgenb, 2001]. The results obtained were in accordance with the immunocytochemical findings. In fact, the gene expression of $F$-actin, $\alpha$-actin, and $\alpha$-tubulin was significantly higher $(P<0.001)$ in the control cells (respectively, 28.4, 40.1, and 18.4 times more), whereas the vimentin gene was more expressed (13 times) in modeled gravitational unloading (Fig. 3B).

A
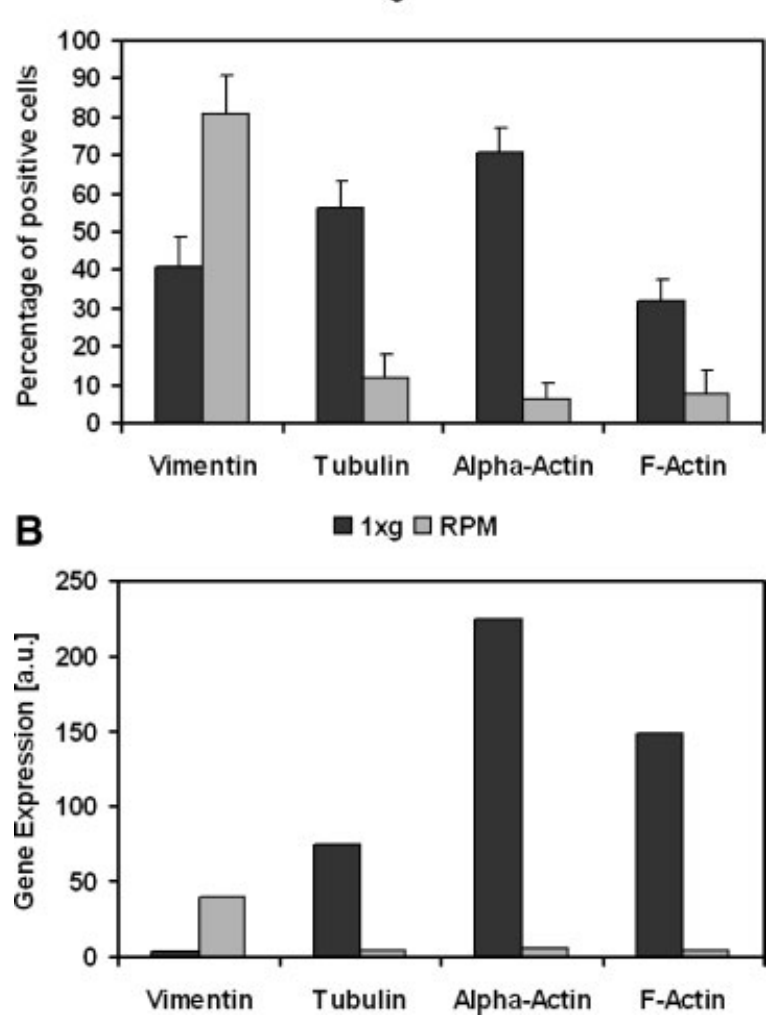

Fig. 3. Cytoskeleton components. Protein (A) and gene (B) expression screened in FLG 29.1 cells cultured in modeled hypogravity and $1 \times \mathrm{g}$ conditions.

\section{Osteoclastic Markers}

The presence of numerous cells (over 50\%) with a morphological appearance reminiscent of the osteoclastic ones, induced us to analyze both phenotypic and genotypic expression of major markers of osteoclastic differentiation.

In FLG 29.1 cells exposed to modeled low g conditions, the phenotypic expression of TRAP, integrin vitronectin receptor $\alpha \mathrm{v} \beta 3$, the receptor activator of NF- $\mathrm{KB}$ (RANK) and its ligand (RANKL), examined by means of cytochemistry and immunocytochemistry, resulted significantly enhanced (Fig. 4A). In particular, TRAP+ and $\alpha \mathrm{v} \beta 3+$ cells increased by about $120 \%$ and $30 \%$, respectively. Cells expressing RANK and RANKL, two molecules that play a fundamental role in osteoclastogenesis [Teitelbaum and Ross, 2003; Troen, 2003], had increased by sixfold $(P<0.001)$ and 10 -fold $(P<0.0001)$, respectively, compared to the $1 \times \mathrm{g}$ control.

In order to confirm these findings, the RNA transcripts of the genes encoding for the
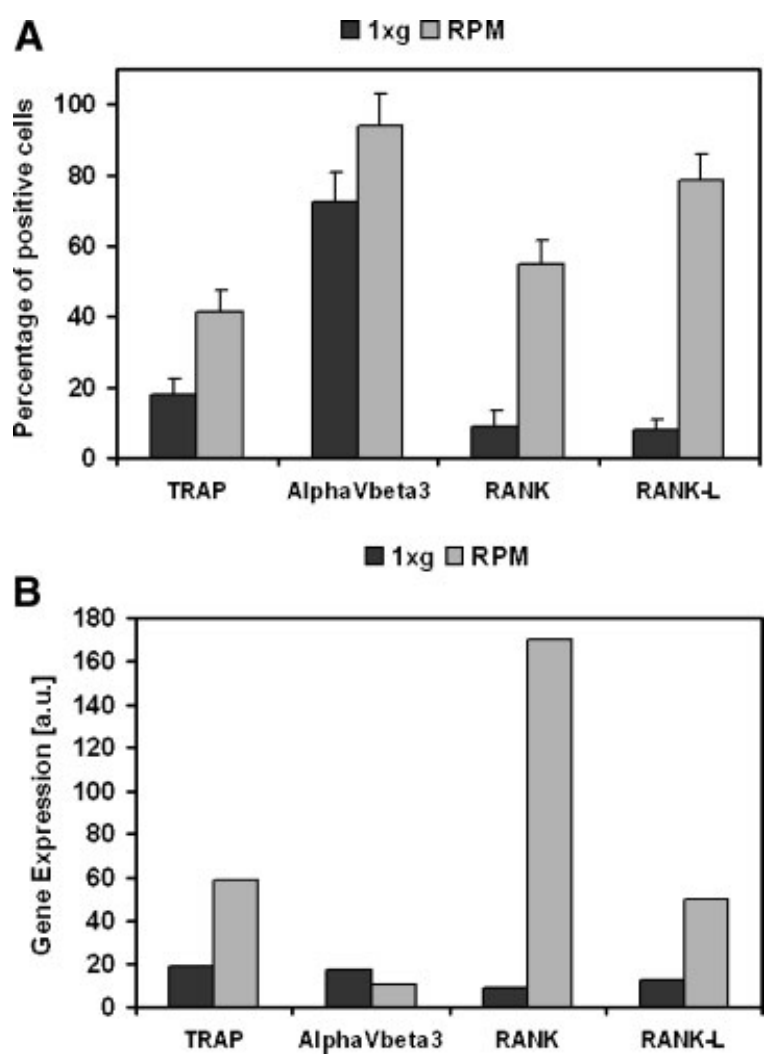

Fig. 4. Markers of osteoclastic differentiation. Protein (A) and gene (B) expression screened in FLG 29.1 cells cultured in modeled hypogravity and $1 \times \mathrm{g}$ conditions. 
above-mentioned markers of osteoclastic differentiation were assayed, too.

The results (Fig. 4B) of RT-PCR showed that the RANK, RANKL, and TRAP genes were more highly expressed $(P<0.0001)$ in conditions of modeled hypogravity (respectively, 19, 4.1, and 3.1 times more) than in the $1 \times \mathrm{g}$ control, in accordance with what was seen at a phenotypic level. On the contrary, $\alpha v \beta 3$ gene expression did not increase.

\section{Bone Resorption Assay}

The ability to resorb bone is a typical characteristic of osteoclasts. Bone resorption activity of FLG 29.1 cells has been assayed by surface profilometry and imaging, as described in "Materials and Methods."
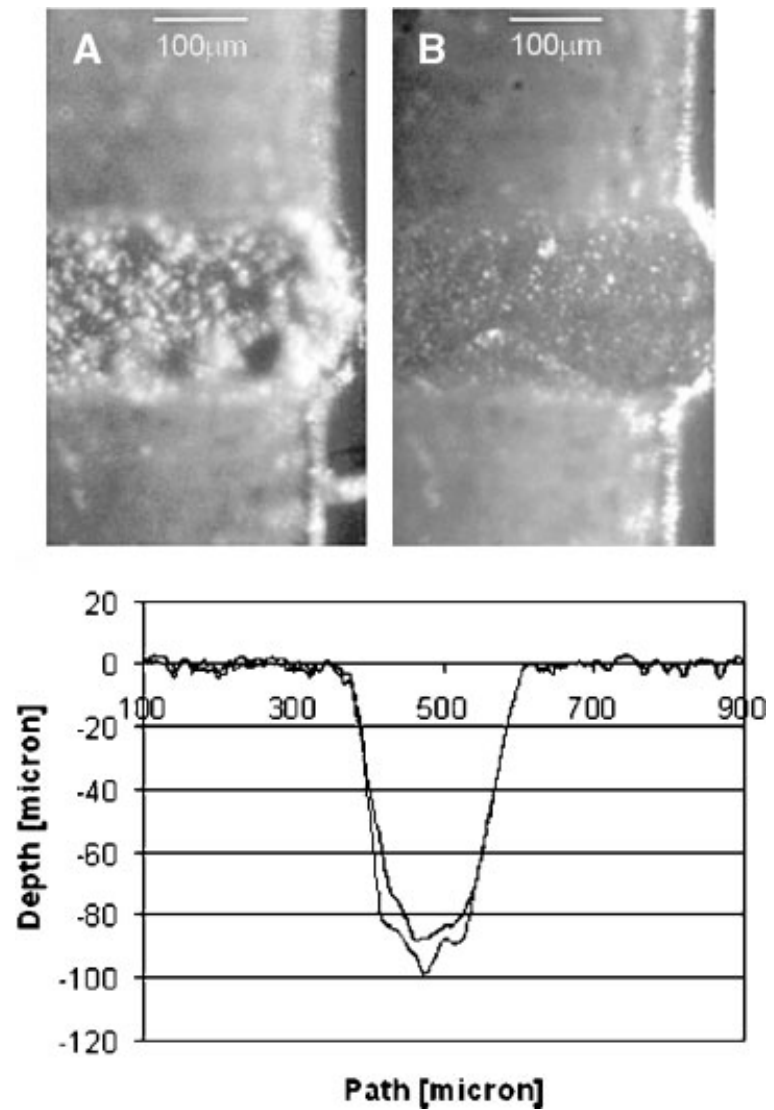

Fig. 5. Bone resorption assay. Top: microscopic images of a bone slice recorded before (A) and after (B) exposure to FLG 29.1 cells in modeled low $g$ conditions. A detail of the bottom of a rut is shown. Bottom: profiles of the same bone slice recorded before (upper line) and after (lower line) exposure to FLG 29.1 cells in modeled low $g$. By comparing the surface profiles it was possible to calculate the volume of resorbed bone. The mean value was $2 \pm 0.5 \mu \mathrm{m}^{3}$ per $\mu \mathrm{m}^{2}$ with values of up to $20 \pm 0.5 \mu \mathrm{m}^{3}$ per $\mu \mathrm{m}^{2}$ on the bottom of the ruts.
As shown in Figure 5, the slices exposed to FLG 29.1 cells in conditions of modeled gravitational unloading showed bone resorption the mean volume of resorbed bone was $2 \pm 0.5 \mu^{3}$ per $\mu \mathrm{m}^{2}$, with a maximum value of $20 \pm 0.5 \mu \mathrm{m}^{3}$ per $\mu \mathrm{m}^{2}$ ), which was not observed in control slices.

Digital wide-field microscopy with a grazing lighting, performed in the same area that was scanned by surface profilometry, confirmed, and imaged bone resorption on the slices from the RPM (Fig. 5). Surface analysis by SEM revealed adherent cells (Fig. 6) and pits on the bone slices from samples exposed to modeled hypogravity.

\section{Apoptosis}

To understand the molecular mechanisms responsible for the significant increase in apoptotic cells observed in the samples kept in the RPM, the phenotypic and genotypic profiles of FLG 29.1 cells were studied with regard to pro- and anti-apoptotic factors.

The expression of the proteins p53, Bax, Fas, FasL, and Bcl-2, determined by immunocytochemistry, is reported in Figure 7A. All these proteins increased in modeled hypogravityexposed cells, compared to the $1 \times \mathrm{g}$ control. Among the pro-apoptotic factors, the expression of p53, a key element in inducing apoptosis in response to DNA damage [Moll and Zaika, 2001], increased slightly. Fas and its ligand FasL, whose binding triggers apoptosis via

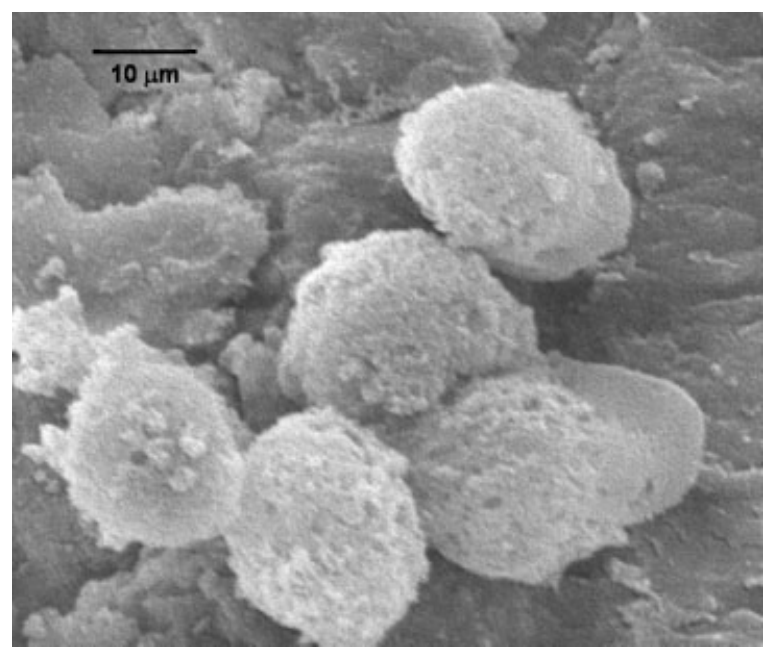

Fig. 6. Scanning Electron Microscopy of a bone slice exposed to FLG 29.1 cells cultured in modeled hypogravity. Adherent cells on the bone surface can be observed. 

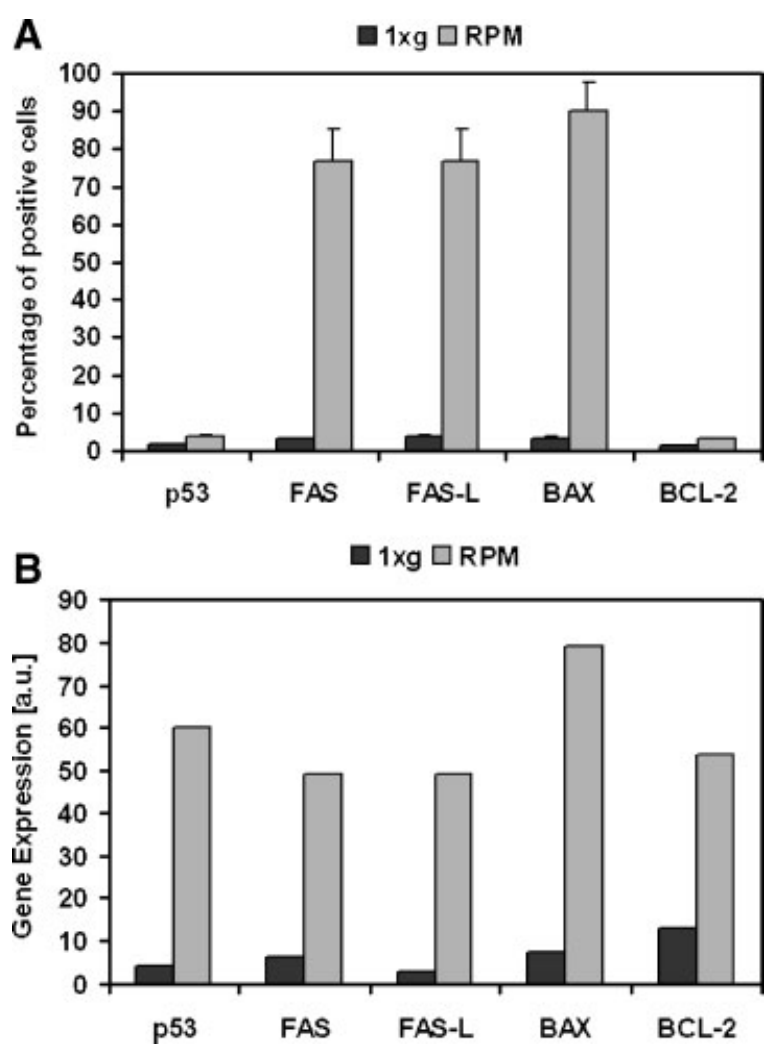

Fig. 7. Factors regulating apoptosis. Protein (A) and gene (B) expression screened in FLG 29.1 cells cultured in modeled hypogravity and $1 \times g$ conditions.

extrinsic pathway [Ashkenazi, 2002], had a significant increase: Fas + and FasL + cells were about $76 \%$ and $77 \%$, respectively, in samples cultured in the RPM, while in the control both Fas+ and FasL+ cells were about 3\% $(P<0.001)$. Bax, a promoter of apoptosis via the intrinsic pathway [Fumarola and Guidotti, 2004], was expressed thirty times more $(P<0.001)$ than in the control. Bcl-2, an antiapoptotic member of the Bcl-2 family [Lawen, 2003], was slightly overexpressed in cells exposed to modeled low g.

The expression trend of the genes encoding for the considered pro- and anti-apoptotic factors was studied using RT-PCR and the findings resulted in accordance with those obtained by protein expression analysis. When compared to the $1 \times \mathrm{g}$ control, the p53, Fas, FasL, and Bax genes were upregulated $(P<0.001)$ in the cells kept in the RPM (about 15, 7.5, 16, and 8 times more, respectively). Bcl-2 gene expression increased fourfold (Fig. 7B).

\section{Multispectral Imaging Autofluorescence Microscopy and Autofluorescence Microspectroscopy}

The AF of living FLG 29.1 cells, both cultured in the RPM and controls, was monitored using Multispectral Imaging Autofluorescence Microscopy (MIAM) and Autofluorescence Microspectroscopy (AMS).

MIAM analysis of control cells showed (Fig. 8A) a quite diffuse cytoplasmic AF, partly blurring the nucleus. The AF emission was more intense in the cell periphery, where few organelles were distinguishable. Intensely fluorescent nucleoli were sometimes observed.

A different AF pattern characterized the cells maintained in the RPM. AF appeared discretely distributed and closely connected with the numerous organelles. Many cells contained two or more non-fluorescent nuclei and vesicles, characterized by an intense green-yellow fluorescence, generally gathered at a cell pole (Fig. 8B). Both MIAM analysis and cytochemical staining gave evidence of intercellular cytoplasmic bridges and cell fusion (data not shown). This phenomenon was previously described by other authors [Geheron Robey et al., 1992].

Many apoptotic cells were observed. They showed blue-green fluorescent blurs, caused by progressive dissolution of cell compartments and consequent spreading of $\mathrm{NAD}(\mathrm{P}) \mathrm{H}$ and flavins all over the cell [Petit et al., 2001]. Membrane blebbing and highly fluorescent spots, due to chromatin condensation, were visible too (Fig. $8 \mathrm{C}$ ).

$\mathrm{NAD}(\mathrm{P}) \mathrm{H}$, both bound and free forms, and oxidized flavins are the main endogenous fluorophores emitting in the blue and green ranges, respectively, and their fluorescence is considered an indicator of the intracellular redox state [Schneckenburger and König, 1992]. Thus, we examined the relationship among intracellular coenzyme pools by AMS.

The spectra of cells cultured in the RPM were compared with control ones both for emission intensity (Fig. 9A) and spectral shape (Fig. 9B) after normalization. The former appeared less intense and broadened towards the greenyellow wavelengths, thus highlighting differences in AF intensity as well as in spectral shape.

The AF spectra showed a peak at $445 \mathrm{~nm}$ and shoulders at about 465 and $530 \mathrm{~nm}$. These wavelengths correspond to the emission peaks 


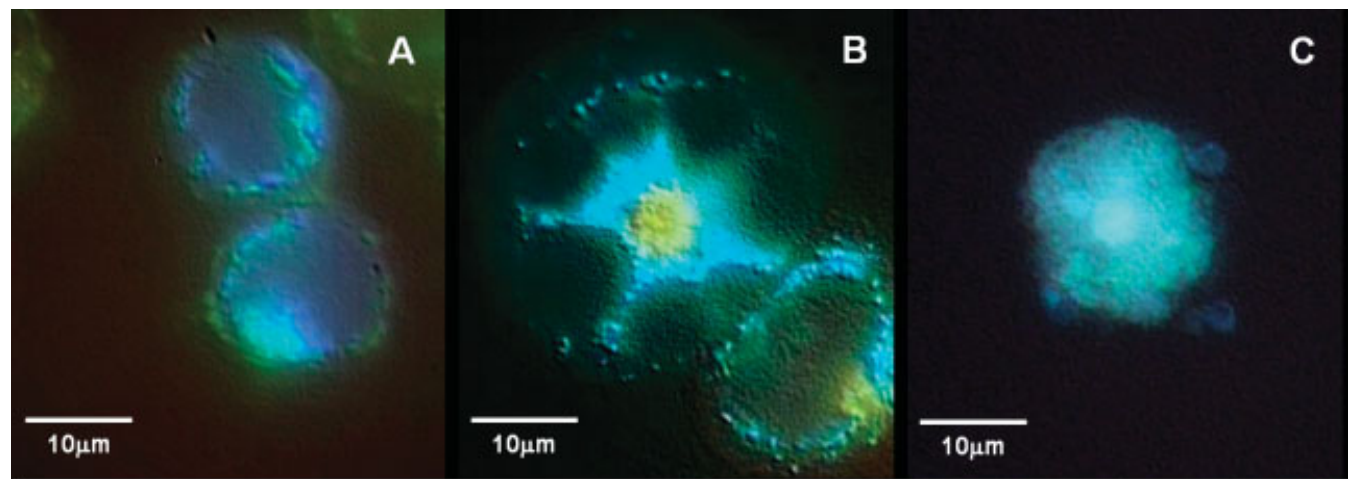

Fig. 8. Autofluorescence imaging of FLG 29.1 cells cultured at $1 \times \mathrm{g}(\mathbf{A})$ and exposed to hypogravity conditions modeled in an RPM (B,C). Very different AF patterns characterize control cells (A), cells showing osteoclast-like features (B) and apoptotic cells (C). See the text for description. Excitation wavelength $365 \mathrm{~nm}$. Fluorescence images were directly digitized in the CCD controller with 14 bit dynamics and transferred to the storage computer on a digital interface. The size of the field detected by the $100 \times$ objective was about $69 \times 69 \mu \mathrm{m}$ (spatial calibration of $0.13 \mu \mathrm{m} /$ pixel), as determined by imaging $6 \mu \mathrm{m}$ diameter fluorescent microspheres (Molecular Probes). For each sample, three $40 \mathrm{~nm}$ wide (full width at half maximum) spectral bands

of the $\mathrm{NAD}(\mathrm{P}) \mathrm{H}$ bound form, $\mathrm{NAD}(\mathrm{P}) \mathrm{H}$ free form and flavins, respectively [Andersson et al., 1998]. Table II reports the AF intensity ratios $445 \mathrm{~nm} / 530 \mathrm{~nm}$ and $465 \mathrm{~nm} / 530 \mathrm{~nm}$, calculated from the spectra of cells kept in modeled hypogravity and controls. In RPM-exposed cells, the ratio values decreased. This means that oxidized flavins increased, in accordance with the broadening of the green component observed in the spectrum. The ratio $445 \mathrm{~nm} / 465 \mathrm{~nm}$ (that is $\mathrm{NAD}(\mathrm{P}) \mathrm{H}$ bound form/ $\mathrm{NAD}(\mathrm{P}) \mathrm{H}$ free form) was also considered, but no significant changes were found.

\section{Cells Re-Cultured at $1 \times \mathrm{g}$ After $72 \mathrm{~h}$ Exposure to the RPM}

To ascertain if the observed induction of the different genetic programs leading to differentiation and apoptosis was or was not a reversible process, part of the cells maintained for $72 \mathrm{~h}$ in the RPM was recovered and then cultured again (initial density $1 \times 10^{5}$ cell $\mathrm{s} / \mathrm{ml}$ ) at $1 \times \mathrm{g}$ in the basic conditions described in the section "Materials and Methods." After 3 weeks, the genotypic and phenotypic profiles of the cells were analyzed again. As shown in Figure 10, the expression of the genes involved in apoptosis regulation decreased at levels even lower than those expressed in the control cells, thus demonstrating that the increase in programmed cell death observed in modeled hypo- peaked at about 450, 550, and $650 \mathrm{~nm}$ (450 FS 40-25, 550 FS 4025 , and 650 FS 40-25, respectively, Andover, Salem, NH) were used in order to sequentially acquire three fluorescence images in blue, green, and red, with integration times of about 5 seconds. Monochrome images were then combined in a single multicolor image using the RGB technique (Wyszecki and Stiles, 1982). The multicolor images were obtained by the Image Combine Channels algorithm of Corel PHOTO-PAINT v 6.0 software (Corel Corporation, Ottawa, Canada) after the identification of the three grayscale images (acquired at 650, 550, and $450 \mathrm{~nm}$, respectively) with the RGB components.

gravity can be reversed by re-culturing the cells at $1 \times \mathrm{g}$. On the contrary, the $R A N K, R A N K L$, and TRAP genes remained markedly overexpressed. The phenotypic expression of RANK, RANKL, and TRAP was higher than in the control too (data not shown). The morphological appearance of very large, multinucleated cells was observed in $70 \%$ of the cell population, suggesting that the cells exposed to modeled hypogravity conditions, even after restoring the basic culture conditions $(1 \times \mathrm{g})$, maintained the characteristics of more differentiated elements, in comparison with the control cells.

\section{DISCUSSION}

It is clear that rotating devices like clinostat, RPM and rotating wall vessel (RWV) do not reduce gravity but rather average the exposure of the biological samples to the gravity vector over the time of incubation in order to minimize g.

The use of rotating devices in cell biology was introduced about two decades ago to complement and prepare experiments to be carried out in real, low g conditions. Today, such devices are widely used because extensive ground-based studies are required before an investigation can be carried out in space laboratories. The validity of the RPM as an experimental model able to produce conditions similar to those occurring 
A

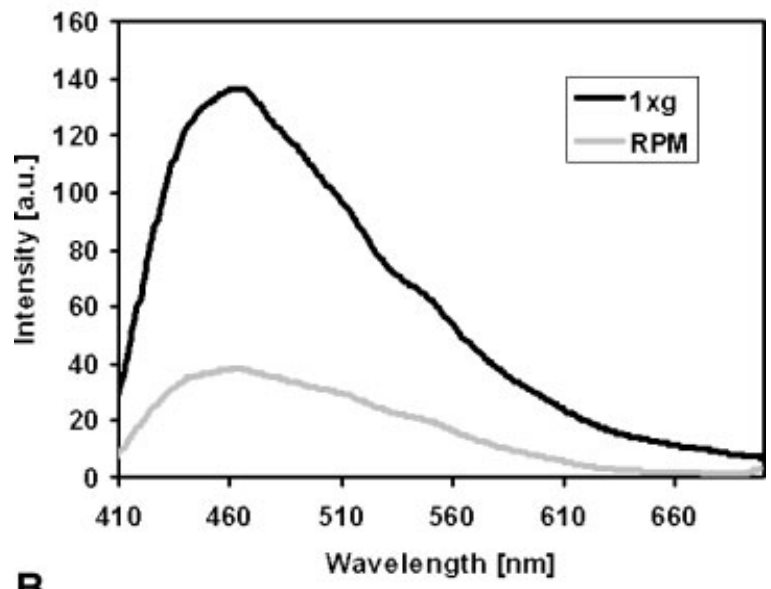

B

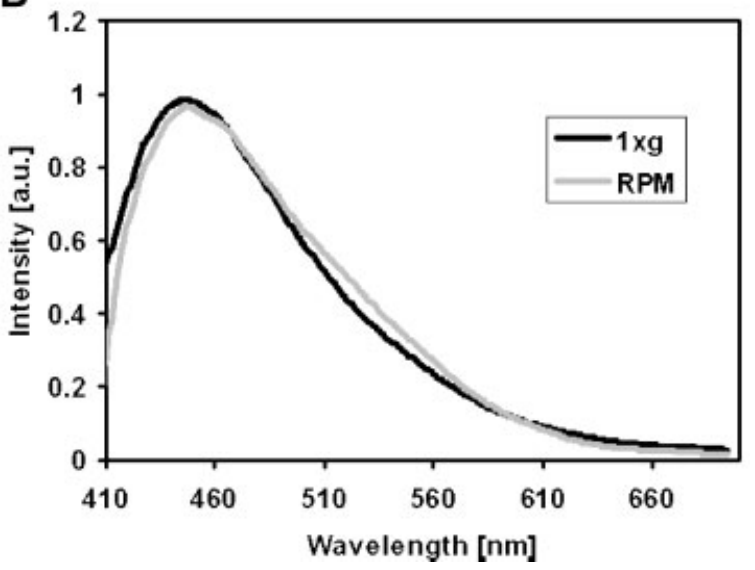

Fig. 9. Autofluorescence spectra of FLG 29.1 cells cultured at $1 \times \mathrm{g}$ and in the RPM. Emission intensity $(\mathbf{A})$ and spectral shape (B), after normalization, are compared. The emission intensity in control cells is higher (about threefold) than in the RPMexposed cells. The latter show a higher contribution of the green component, mostly due to oxidized flavins. Fluorescence spectra were recorded through a band-pass filter (GG400, Schott) in order to remove UV excitation, and collected over a spot of about $10 \mu \mathrm{m}$ in diameter, as estimated by using $6 \mu \mathrm{m}$ diameter fluorescent microspheres (F-14808, Molecular Probes, Leiden, The Netherlands). Fluorescence spectra, recorded with a 24 seconds integration time, were corrected for the optical system spectral response and smoothed by a Gaussian convolution algorithm. After correction, the spectra were normalized to their respective peaks as $100 \%$ for comparison.

during exposure of cells to microgravity has been proved by comparing data obtained in space experiments with those obtained in the RPM, as well as in other rotating devices [Cooper and Pellis, 1998; Schwarzenberg et al., 1999].

The concern that shear force may stress the cells should also be addressed. Shear force is generated in all the rotating devices. However, the experiments here described have been carried out utilizing culture chambers that
TABLE II. Ratios of Autofluorescence Intensity Values at 445, 465, and $530 \mathrm{~nm}$ in FLG 29.1 Cells Exposed to Modeled Hypogravity and Controls

\begin{tabular}{lcc}
\hline $\begin{array}{l}\text { Ratio description } \\
\text { (wavelengths) }\end{array}$ & $\begin{array}{c}\text { Control }(1 \times \mathrm{g}) \\
(\text { value } \pm \sigma)\end{array}$ & $\begin{array}{c}\text { RPM } \\
\text { (value } \pm \sigma)\end{array}$ \\
\hline $445 \mathrm{~nm} / 530 \mathrm{~nm}$ & $2.61 \pm 0.16$ & $2.19 \pm 0.16$ \\
$465 \mathrm{~nm} / 530 \mathrm{~nm}$ & $2.41 \pm 0.16$ & $2.06 \pm 0.19$ \\
\hline
\end{tabular}

The considered wavelengths correspond to the peaks of $\mathrm{NADHb}$, NADHf, and flavins, respectively. The mean values on 10 cells have been reported. Both the ratios $445 \mathrm{~nm} / 530 \mathrm{~nm}$ and $465 \mathrm{~nm} /$ $530 \mathrm{~nm}$ decreased in modeled hypogravity-exposed cells compared to the control, thus denoting the increase in oxidized flavins.

almost completely exclude the presence of air bubbles by means of a mobile piston, thus shear effects are significantly reduced and do not affect appreciably the results [Schwarzenberg et al., 1999]. In conclusion, there is convincing experimental evidence on the validity of the model here used to produce modeled microgravity conditions.

The morphological analysis of FLG 29.1 cells cultured for $72 \mathrm{~h}$ in RPM revealed two intriguing effects: (1) about 50\% of the cells showed characteristics typical of osteoclasts, (2) about $40 \%$ of the cells showed signs of apoptosis.

Recent studies in osteoclastic cell biology have led to breakthroughs in the understanding of osteoclastic differentiation and activation. In particular, it has been unambiguously demonstrated that the binding between the receptor activator of $\mathrm{NF}-\kappa \mathrm{B}$ (RANK), present on the plasma membrane of both osteoclastic precursors and mature osteoclasts, and its ligand (RANKL), produced by osteoblasts and stromal cells in response to a variety of signals, activates signal transduction pathways that ultimately lead to osteoclastic differentiation and increased osteoclastic activity [Lacey et al., 1998; Yasuda et al., 1998; Boyle et al., 2003; Miyamoto and Suda, 2003].

FLG 29.1 cells cultured in the RPM showed upregulation of RANK and RANKL genes and a marked increase in both RANK and RANKL expression, compared to the $1 \times \mathrm{g}$ controls. It is noteworthy that overexpression of RANK and RANKL was not abolished when cells were recovered from the RPM and cultured again in standard conditions at $1 \times \mathrm{g}$ for 3 weeks.

These results support the hypothesis that culturing in modeled weightlessness induces differentiation of FLG 29.1 through the osteoclastic pathway, via paracrine/autocrine 


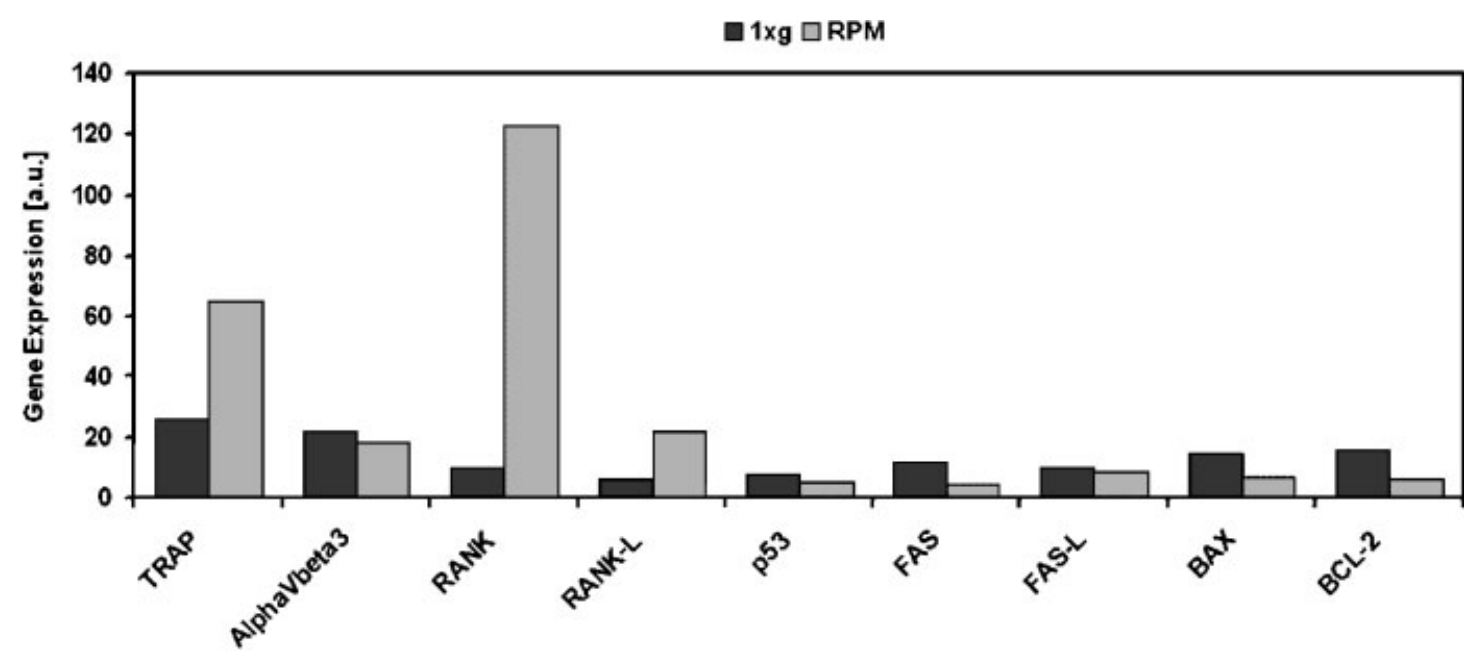

Fig. 10. Markers of osteoclastic differentiation and factors regulating apoptosis. Gene expression screened in FLG 29.1 cells cultured in modeled hypogravity for $72 \mathrm{~h}$ and then recultured at $1 \times \mathrm{g}$ for 3 weeks, compared to the controls (always kept at $1 \times \mathrm{g}$ ).

production of RANKL. In addition to the overexpression of RANK and RANKL, the findings on morphology, expression of other osteoclastic markers, and bone resorption in RPM-exposed cell cultures are consistent with this hypothesis as well.

As indicated above, after culturing in the RPM, numerous bi- or multi-nucleated cells with enhanced dimensions, cell fusion and presence of cytoplasmic bridges connecting the cells were observed. It is well known that multinucleation, brought about by the fusion of mononuclear cells, is a characteristic feature of osteoclasts [Miyamoto and Suda, 2003]. TRAP and $\alpha \mathrm{v} \beta 3$, which are generally considered major criteria for osteoclastic characterization, were significantly more expressed in cells exposed to modeled hypogravity. In the case of TRAP, the enhanced phenotypic expression corresponded to an increased gene transcription, while post-transcriptional mechanisms could be hypothesized to explain the apparent discrepancy between phenotypic and genotypic expression of $\alpha \mathrm{v} \beta 3$.

The principal function of mature osteoclasts is bone resorption. Recently, it was demonstrated that RANKL exerts a pro-resorbing activity through an overall enhancing effect on osteoclastic marker (TRAP, cathepsin K, etc.) expression [Wittrant et al., 2003]. FLG 29.1 cells cultured in standard conditions at $1 \times \mathrm{g}$ are immature elements unable to adhere to or resorb bone. In fact, as expected, no resorption activity was found in bone slices from the control samples at $1 \times \mathrm{g}$. On the contrary, a mean value of resorbed bone volume equal to $2 \pm 0.5 \mu \mathrm{m}^{3}$ per $\mu \mathrm{m}^{2}$ was found in the bone slices from samples exposed to modeled low g. This value is in accordance with data reported by Boyde and Jones [1992], who reviewed the more reliable methods used in the study of shape and dimension of Howship's lacunae in order to extrapolate the volume of resorbed bone. Surface analysis by SEM and Digital wide-field microscopy with grazing lighting gave visual evidence that FLG 29.1 cells cultured in the RPM were able to adhere to the bone surface and resorb bone.

The AF analysis showed important differences between cells kept in the RPM and the controls with regard to (i) emission intensity, (ii) the relative contribution of the different endogenous fluorophores to the total emission, (iii) the intracellular distribution of the endogenous fluorophores.

The total emission intensity was lower in modeled hypogravity-exposed cells than in the control ones. It has been demonstrated that $\mathrm{AF}$ emission arising from poorly differentiated cells is higher than that from the corresponding more mature elements [Monici et al., 2003]. The intensity decrease was accompanied with changes in the relative contributions of both $\mathrm{NAD}(\mathrm{P}) \mathrm{H}$ and flavins to the total AF: the former decreased while the latter increased, as drawn from the variations in $\mathrm{AF}$ intensity ratios (Table II). This means that in modeled hypogravity, cell energy metabolism was characterized by a higher aerobic component compared to the control cell metabolism, where the anaero- 
bic component was more important. It is known that the flavin concentration is significantly reduced in poorly differentiated cell types, due to a deficient aerobic oxidation system, compared to more differentiated elements [Anidjar et al., 1996]. Moreover, a less efficient aerobic component gives rise to an increase in the reduced forms of pyridinic coenzymes [ObiTabot et al., 1993]. The AF pattern of the cells exposed to modeled low $\mathrm{g}$ further supported the presence of a more efficient aerobic component. In fact, the blue and green components, due to $\mathrm{NAD}(\mathrm{P}) \mathrm{H}$ and flavins, respectively, appeared co-localized in numerous discrete sites generally surrounding the dark nuclei. On the contrary, in control cells, the discrete fluorescent sites were strongly reduced and a homogeneous fluorescence was spread in the cytoplasm. It has been demonstrated that the intracellular autofluorescent sites co-localize with mitochondria and, to a lesser extent, with lysosomes [Andersson et al., 1998]. Therefore, our findings assessed a higher content of mitochondria in the cells cultured in modeled hypogravity than in the control ones. As reported in the literature, a connection exists between the quantity of mitochondria and the type of energy metabolism: a decrease in the aerobic component is linked to a decrease in mitochondria [Pedersen, 1978]. On the other hand, the homogeneous cytoplasmic $\mathrm{AF}$ found in the controls fits very well with the prevalence of the anaerobic component; anaerobic metabolism involves less interactions between coenzymes and cell structures.

In conclusion, the decrease in AF intensity, the distribution of the endogenous fluorophores and their relative contribution to the total fluorescence indicate that the cells cultured in modeled gravitational unloading exhibit an energy metabolism more aerobic than that of the control cells, in accordance with the hypothesis that the former have reached a higher degree of maturation than the latter.

It is noteworthy that cells exposed to modeled hypogravity showed characteristic green-yellow fluorescent vesicles gathered at a cell pole. Further research is needed to understand both composition and function of the vesicles and to ascertain their similarity with those described in mature and active osteoclasts by other authors [Salo et al., 1997; Väänänen et al., 2000].

It is noteworthy that cells exposed to modeled hypogravity showed characteristic green-yel- low fluorescent vesicles gathered at a cell pole. Further research is needed to understand both composition and function of the vesicles and to ascertain their similarity with those described in mature and active osteoclasts by other authors [Salo et al., 1997; Väänänen et al., 2000].

Interestingly enough, our results demonstrate that culturing in modeled weightlessness induces preosteoclastic cells to undertake a differentiation process and stimulates bone resorption activity, while other authors demonstrated that exposure of rat bone marrow cells to cyclic pressure (in order to simulate the pressure conditions that bone marrow cells may be subjected to in vivo) resulted in decreased formation of osteoclastic cells from progenitors, reduced mRNA expression of regulators of osteoclast function, and reduced bone resorption activity [Nagatomi et al., 2002].

In addition to the presence of cells showing osteoclastic-like features, another relevant effect observed in RPM cell cultures was the marked increase of apoptotic cells.

Several authors reported an increase in apoptosis in different cell types cultured both in real and modeled hypogravity [Lewis et al., 1998; Schatten et al., 2001; Grimm et al., 2002]. Moreover, the involvement of both the extrinsic and intrinsic pathways was demonstrated. In cells exposed to low $g$, enhanced expression of the death receptor Fas, activating the extrinsic pathway, was detected [Lewis et al., 1998; Grimm et al., 2002]. It was also found that hypogravity-induced apoptosis is accompanied by an alteration of the cytoskeleton, resulting in redistribution and then dissolution of the mitochondria [Schatten et al., 2001; Kossmehl et al., 2003], as occurs in the intrinsic mitochondrial-mediated cell death program [Shimizu et al., 2000].

The results presented here strongly confirm the above-mentioned studies and support the hypothesis of the involvement of both the intrinsic and extrinsic pathways. In fact, in FLG 29.1 cells exposed to the RPM, both Fas and FasL resulted overexpressed, compared to the controls, thus suggesting the triggering of the extrinsic pathway. In accordance with data reported by other authors [Grimm et al., 2002; Uva et al., 2002; Carlsson et al., 2003], we found cytoskeletal alterations as well. In particular, the cytoskeletal intermediate filament protein vimentin increased, while $\alpha$-actin, $F$-actin, 
and tubulin decreased. In addition to cytoskeletal disorganization, mitochondrial damage occurred in a high percentage (about $40 \%$ ) of the cells cultured in the RPM, as clearly appeared by analyzing the altered AF pattern, characterized by the disappearance of the intracellular organelles and formation of bluegreen fluorescent haloes due to the passage of intra-organelle content into the cytoplasm [Petit et al., 2001]. The overexpression of Bax observed in cells exposed to modeled hypogravity, in accordance with the findings of other authors [Kossmehl et al., 2003], further supports the involvement of the intrinsic pathway. Indeed, Bax is a pro-apoptotic factor responsible for pore formation in mitochondrial membranes [Gross et al., 1999]. Permeabilization of the outer mitochondrial membrane is followed by release of proapoptotic proteins, able to activate caspases, and then the apoptotic cascade [Fumarola and Guidotti, 2004]. In apparent discrepancy with the increase in apoptosis in RPM-exposed cells, the expression of the antiapoptotic factor Bcl-2 resulted enhanced. Therefore, the rise in Bcl-2 expression was lower than that observed in Bax and, in accordance with the rheostat hypothesis [Korsmeyer, 1995], it is the relative level of pro- and anti-apoptotic proteins that determine the cell's susceptibility to apoptosis.

In conclusion, the findings described here demonstrate that cells from the FLG 29.1 line, an osteoclastic precursor model, are directly sensitive to gravitational alterations. Culturing in the RPM heavily affects cytoskeleton organization, thus supporting the widely accepted hypothesis that the cytoskeleton plays a key role in cell gravisensing, as well as in firing weightlessness-induced apoptosis. The large increase in apoptosis, observed in FLG 29.1 cells exposed to modeled low g, confirms results previously obtained by other authors studying different kinds of cells. However, as far as we know, this is the first time the triggering effect of modeled hypogravity on apoptosis, via molecular mechanisms involving both the extrinsic and intrinsic pathways, is described in preosteoclastic cells.

Most importantly, this study reports very significant and novel findings about the effect of gravitational alterations on preosteoclastic differentiation. In addition to the triggering of apoptosis, random gravity induced the surviving cells to undertake a differentiation process along the osteoclastic pathway, via a paracrine/ autocrine mechanism characterized not only by overexpression of RANK but also by upregulation of its ligand RANKL. Convincing experimental evidence of this occurrence is provided by comparing FLG 29.1 cells cultured in the $\mathrm{RPM}$ with the controls at $1 \times \mathrm{g}$ with regards to morphology, expression of osteoclastic markers, cell metabolism, and bone resorption activity.

These intriguing results suggest a new mechanism that, together with many other factors, could contribute to causing the decrease in bone mass observed in crewmembers after space flights. A more general speculation could be made on the possibility of modulating cell differentiation by mechanical and gravitational stimuli, which might be of consequence in tissue engineering. Finally, the experimental model proposed could become a useful tool for studies on induced bone regeneration as well as on the physiopathology of osteoporosis and other bone diseases.

\section{ACKNOWLEDGMENTS}

The authors thank Prof. J. Paul Veldhuijzen for his discussions and suggestions regarding our study, Dr. Venere Basile, Giovanni Romano, and Antonino Labate for their collaboration on data processing and image analysis.

\section{REFERENCES}

Andersson H, Baechi T, Hoechl M, Richter C. 1998. Autofluorescence of living cells. J Microsc 191:1-7.

Anidjar M, Cussenot O, Blais J, Bourdon O, Avrillier S, Ettori D, Villette JM, Fiet J, Teillac P, Le Duc A. 1996. Argon laser induced autofluorescence may distinguish between normal and tumor human urothelial cells: A microspectrofluorometric study. J Urol 155:1771-1774.

Ashkenazi A. 2002. Targeting death and decoy receptors of the tumor necrosis factor superfamily. Nat Rev Cancer 2: $420-430$.

Bikle DD, Sakata T, Halloran BP. 2003. The impact of skeletal unloading on bone formation. Gravit Space Biol Bull 16(2):45-54.

Boyde A, Jones SJ. 1992. Really close up! Surveying surfaces at sub-micrometre resolution: The measurement of osteoclastic resorption lacunae. Photogramm Rec 14(79):59-84.

Boyle WJ, Simonet WS, Lacey DL. 2003. Osteoclast differentiation and activation. Nature 423:337-342.

Brown TD. 2000. Techniques for mechanical stimulation of cells in vitro: A review. J Mech 33:3-14.

Carlsson SIM, Bertilaccio MTS, Ballabio E, Maier JAM. 2003. Endothelial stress by gravitational unloading: Effects on cell growth and cytoskeletal organization. Biochim Biophys Acta 1642:173-179. 
Carmeliet G, Vico L, Bouillon R. 2001. Space flight: A challenge for normal bone homeostasis. Crit Rev Eukaryot Gene Expr 11:131-144.

Chance B. 1989. Microspectroscopy and flow cytomentry. In: Kohen E, Hirschberg JG, editors. Cell structure and function by microspectrofluorometry. San Diego, CA: Academic Press, pp 53-691.

Cogoli A, Tschopp A, Fuchs-Bislin P. 1984. Cell sensitivity to gravity. Science 225:228-230.

Cogoli A, Bechler B, Müller O, Hunzinger E. 1988. Effect of microgravity on lymphocyte activation. In: Longdon N, David V, editors. Biorack on Spacelab D1. ESA, Noordwijk, The Netherlands, SP-1091. pp 89-100.

Cooper D, Pellis NR. 1998. Suppressed PHA activation of T lymphocytes in simulated microgravity is restored by direct activation of protein kinase. C J Leukoc Biol 63: $550-562$

Dike LE, Chen CS, Mrksich M, Tien J, Whitesides GM, Ingber DE. 1999. Geometric control of switching between growth, apoptosis and differentiation during angiogenesis using micropatterned substrates. In Vitro Cell Dev Biol Anim 35:441-448.

Frost HM. 1988. Vital biomechanics: Proposed general concepts for skeletal adaptations to mechanical usage. Calcif Tissue Int 42:145-156.

Fumarola C, Guidotti GG. 2004. Stress-induced apoptosis: Toward a symmetry with receptor-mediated cell death. Apoptosis 9:77-82.

Fusi F, Agati G, Monici M, Pratesi R, Romano S, Bernabei PA. 2002. Multicolor Imaging Autofluorescence Microscopy: A new technique for the discrimination of normal and neoplastic tissues and cells In: Pandalai SG, editor. Recent Research Development in Photochemistry and Photobioloby. Trivandrum, India: Transword Research Network, pp 79-93. ISBN: 81-7895-053-7.

Fusi F, Mercatelli L, Basile V, Pucci M, Siano S, Bernabei PA, Monici M. 2005. A new method based on contact surface profilometry for quantitative measurement of resorbed bone volume. Phys Medica 21:41-46.

Gattei V, Bernabei PA, Pinto A, Bezzini R, Ringressi A, Formigli L, Tanini A, Attadia V, Brandi ML. 1992. Phorbol ester induced osteoclast-like differentiation of a novel human leukemic cell line (FLG 29.1). J Cell Biol 116:437-477.

Geheron Robey P, Grzesik WJ, Formigli L, Masi L, Bernabei PA, Brandi ML. 1992. Attachment of FLG 29.1 preosteoclastic cells to byosintetic products of cells in the osteoblastic lineage. In: Cohn DV, Gennari C, Jr., Tashjian AH, editors. Calcium regulating hormones and bone metabolism. Elsevier, Amsterdam, pp 328332.

Gmünder FK, Cogoli A. 1996. Effect of space flight on lymphocyte function and immunity. In: Fregly MJ, Blatteis CM, editors. Handbook of Physiology, Vol. 2. Oxford: University Press, pp 799-813.

Grimm D, Bauer J, Kossmehl P, Shakibaei M, Schoberger J, Pickenhahn H, Schulze-Tanzil G, Vetter R, Eilles C, Paul M, Cogoli A. 2002. Simulated microgravity alters differentiation and increases apoptosis in human follicular thyroid carcinoma cells. FASEB J 16: 604-606.

Gross A, McDonnell JM, Korsmeyer SJ. 1999. Bcl-2 family members and the mitochondria in apoptosis. Genes Dev 13:1899-1911.
Hammond TG, Lewis FC, Goodwin TJ, Linnehan RM, Wolf DA, Hire KP, Campbell WC, Benes E, O'Reilly KC, Globus RK, Kaysen JH. 1999. Gene expression in space. Nat Med 5:359-364.

Hashemi BB, Penkala JE, Vens C, Huls H, Cubbage M, Sams CF. 1999. T cell activation responses are differentially regulated during clinorotation and in spaceflight. FASEB J 13:2071-2082.

Hoson T, Kamisaka S, Masuda Y, Yamashita M, Buchen B. 1997. Evaluation of the three-dimensional clinostat as a simulator of weightlessness. Planta 203:S187-S197.

Hughes-Fulford M. 2003. Function of the cytoskeleton in gravisensing during spaceflight. Adv Space Res 32:15851593.

Hughes-Fulford M, Tjandrawinata R, Fitzgerald J, Gasuad K, Gilbertson V. 1998. Effects of microgravity on osteoblast growth. Gravit Space Biol Bull 11(2):51-60.

Ingber DE. 1997. Tensegrity: The architectural basis of cellular mechanotransduction. Ann Rev Physiol 59:575599.

Kanematsu M, Yoshimura K, Takaoki M, Sato A. 2002. Vector-averaged gravity regulates gene expression of receptor activator of NF- $\mathrm{kB}$ (RANK) ligand and osteoprotegerin in bone marrow stromal cells via cyclic AMP/ protein kinase A pathway. Bone 30:553-558.

Kaplansky AS, Durnova GN, Burkovskaya TE, Vorotnikova EV. 1991. The effect of microgravity on bone fracture healing in rats flown on Cosmos 2044. Physiologist 34:196-199.

Korsmeyer SJ. 1995. Regulators of cell death. Trends Genet 11:101-105.

Kossmehl P, Shakibaei M, Cogoli A, Infanger M, Curcio F, Schonberger J, Eilles C, Bauer J, Pickenhahn H, Schulze-Tanzil G, Paul M, Grimm D. 2003. Weightlessness induced apoptosis in normal thyroid cells and papillary thyroid carcinoma cells via extrinsic and intrinsic pathways. Endocrinology 144:4172-4179.

Kurata K, Ucmura T, Nemoto A, Tateishi T, Muratami T, Higaki H, Miura H, Iwamoto Y. 2001. Mechanical strain effect on bone-resorbing activity and messenger RNA expressions of marker enzymes in isolated osteoclast culture. J Bone Miner Res 16:722-730.

Lacey DL, Timms E, Tan HL, Kelley MJ, Dunstan CR, Burgess T, Elliott R, Colombero A, Elliott G, Scully S, Hsu H, Sullivan J, Hawkins N, Davy E, Capparelli C, Eli A, Qian YX, Kaufman S, Sarosi I, Shalhoub V, Senaldi G, Guo J, Delaney J, Boyle WJ. 1998. Osteoprotegerin ligand is a cytokine that regulates osteoclast differentiation and activation. Cell 93:165-176.

Lawen A. 2003. Apoptosis-An introduction. BioEssays 25: 888-896

Lewis ML, Reynolds JL, Cubano LA, Hatton JP, Lawless BD, Piepmeier EH. 1998. Spaceflight alters microtubule structure and increase apoptosis in human lymphocytes (Jurkat). FASEB J 12:1007-1018.

Livak KJ, Schmittgenb TD. 2001. Analysis of relative gene expression data using real time quantitative PCR and the $2^{-\Delta \Delta \mathrm{Ct}}$ method. Methods 25:402-408.

McAllister TN, Du T, Frangos JA. 2000. Fluid shear stress stimulates prostaglandin and nitric oxide release in bone marrow-derived preosteoclast-like cells. Biochem Biophys Res Commun 270:643-648.

Miyamoto T, Suda T. 2003. Differentiation and function of osteoclasts. Keio J Med 52:1-7. 
Moll UM, Zaika A. 2001. Nuclear and mitochondrial apoptotic pathways of p53. FEBS Lett 493:65-69.

Monici M, Agati G, Fusi F, Pratesi R, Paglierani M, Santini V, Bernabei PA. 2003. Dependence of leukemic cell autofluorescence patterns on the degree of differentiation. Photochem \& Photobiol Sci 2:981-987.

Morey-Holton ER, Wahlen RT, Arnaud SB, Van Der Meulen M. 1996. The skeleton and its adaptation to gravity. In: Fregly MJ, Blatteis CM, editors. Handbook of Physiology, Vol. 1. Oxford: University Press, pp 691-719.

Moss JP, Linney AD, Grindrod LD, Mosse CA. 1989. A laser scanning system for the measurement of facial surface morphology. Opt Laser Eng 10:179-190.

Nagatomi J, Arulandam BP, Metzger DW, Meuinier A, Bizios R. 2001. Frequency- and duration-dependent effects of cyclic pressure on select bone cell functions. Tissue Eng 7:717-728.

Nagatomi J, Arulandam BP, Metzger DW, Meuinier A, Bizios R. 2002. Effects of cyclic pressure on bone marrow cell cultures. J Biomech Engineering 124:308-314.

Obi-Tabot ET, Hanrahan LM, Cachecho R, Beer ER, Opkins SR, Chan JCK, Shapiro JM, La Morte WW. 1993. Changes in hepatocyte NADH fluorescence during prolonged hypoxia. J Surg Res 55:575-580.

Ontiveros C, McCabe LR. 2003. Simulated microgravity suppresses osteoblast phenotype, Runx2 levels and AP-1 transactivation. J Cell Biochem 88(3):427-437.

Papaseit C, Pochon N, Tabony J. 2000. Microtubule selforganization is gravity-dependent. J Proc Natl Acad Sci 97:8364-8368.

Pedersen PL. 1978. Tumor mitochondria and the bioenergetics of cancer cells. Prog Exp Tumor Res 22:190-274.

Petit PX, Gendron M-C, Schrantz N, Métivier D, Kroemer G, Maciorowska Z, Sureau F, Koester S. 2001. Oxidation of pyridine nucleotides during Fas- and ceramideinduced apoptosis in Jurkat cells: Correlation with changes in mitochondria, glutathione depletion, intracellular acidification and caspase 3 activation. Biochem $\mathrm{J}$ 353:357-367.

Roclofsen J, Klein-Nulend J, Burger E. 1995. Mechanical stimulation by intermittent hydrostatic compression promotes bone-specific gene expression in vitro. $\mathrm{J}$ Biomech 28:1493-1503.

Rubin J, Fan X, Biskobing DM, Taylor WR, Rubin CT. 1999. Osteoclastogenesis is repressed by mechanical strain in an in vitro model. J Orthoped Res 17:639-645.

Salo J, Lehenkari P, Mulari M, Metsikkö K, Väänänen HK. 1997. Removal of osteoclast bone resorption products by transcytosis. Science 276:270-273.

Sarkar D, Nagaya T, Koga K, Nomura Y, Gruener R, Seo H. 2000. Culture in vector-averaged gravity under clinostat rotation results in apoptosis of osteoblastic ROS 17/2.8 cells. J Bone Miner Res 15(3):489-498.

Schatten H, Lewis ML, Chakrabarti A. 2001. Spaceflight and clinorotation cause cytoskeleton and mitochondria changes and increases in apoptosis in cultured cells. Acta Astronaut 49:399-418.

Schmitt DA, Hatton JP, Emond C, Chaput D, Paris H, Levade T, Cazenave JP, Schaffar L. 1996. The distribution of protein kinase $\mathrm{C}$ in human leukocytes is altered in microgravity. FASEB J 10:1627-1634.

Schneckenburger H, König K. 1992. Fluorescence decay Kinetics and imaging of $\mathrm{NAD}(\mathrm{P}) \mathrm{H}$ and flavins as metabolic indicators. Opt Eng 31:1447-1451.
Schwartz Z, Lohmann CH, Wieland M, Cochran DL, Dean DD, Textor M, Bonewald LF, Boyan BD. 2000. Osteoblast proliferation and differentiation on dentin slices are modulated by pre-treatment of the surface with tetracycline or osteoclasts. J Periodontol 71:586-597.

Schwarzenberg M, Pippia P, Meloni MA, Cossu G, CogoliGreuter M, Cogoli A. 1999. Signal transduction in T lymphocytes- A comparison of the data from space, the free fall machine and the random positioning machine. Adv Space Res 24:793-800.

Shimizu S, Konishi A, Kodama T, Tsujimoto Y. 2000. BH4 domain of anti-apoptotic Bcl-2 family members closes voltage-dependent anion channel and inhibits apoptotic mitochondrial changes and cell death. Proc Natl Acad Sci 97:3100-3105.

Stanford C, Morcuende J, Brand R. 1995. Proliferative and phenotypic responses of bone-like cells to mechanical deformation. J Orthop Res 13:664-670.

Suda T, Takahashi N, Martin TJ. 1992. Modulation of osteoclast differentiation. Endocr Rev 13:66-80.

Teitelbaum SL, Ross FP. 2003. Genetic regulation of osteoclast development and function. Nat Rev Genet $4: 638-649$

Troen BR. 2003. Molecular mechanisms underlying osteoclast formation and activation. Exp Gerontol 38:605614.

Uva BM, Masini MA, Sturla M, Prato P, Passalacqua M, Giuliani M, Tagliaferro G, Strollo F. 2002. Clinorotationinduced weightlessness influences the cytoskeleton of glial cells in culture. Brain Res 934:132-139.

Van Loon JJ, Bervoets DJ, Burger EH, Dieudonne' SC, Hagen JV, Semeins CM, Zandieh Doulabi B, Veldhuijzen JP. 1995. Decreased mineralization and increased calcium release in isolated fetal mouse long bones under near weightlessness. J Bone Miner Res 10:550-557.

Vico L, Bourrin S, Genty C, Palle S, Alexandre C. 1993. Histomorphometric analyses of cancellous bone from Cosmos 2044 rats. J Appl Physiol 75:2203-2208.

Väänänen HK, Zhao H, Mulari M, Hallen JM. 2000. The cell biology of osteoclast function. J Cell Sci 113:377-381.

Walsh CA, Beresford JN, Birch MA, Boothroyd B, Gallagher JA. 1991. Application of reflected light microscopy to identify and quantitate resorption by isolated osteoclasts. J Bone Miner Res 6:661-671.

Walther I, Pippia P, Meloni MA, Turrini F, Mannu F, Cogoli A. 1998. Simulated microgravity inhibits the genetic expression of interleukin-2 and its receptor in mitogen-activated T lymphocytes. FEBS lett 436:115118.

Wittrant Y, Theoleyre S, Couillaud S, Dunstan C, Heymann D, Rédini F. 2003. Regulation of osteoclast protease expression by RANKL. Biochem Biophys Res Commun 310:774-778.

Wyszecki G, Stiles WS. 1982. Color Science: Concepts and Methods, Quantitative Data and Formulae, 2nd edition. New York: John Wiley \& Sons, 950p.

Yasuda H, Shima N, Nakagawa N, Yamaguchi K, Kinosaki M, Mochizuki SI, Tomoyasu A, Yano K, Goto M, Murakami A, Tsuda E, Morinaga T, Higashio K, Udagawa N, Takahashi N, Suda T. 1998. Osteoclast differentiation factor is a ligand for osteoprotegerin/ osteoclastogenesis-inhibitory factor and is identical to TRANCE/RANKL. Proc Natl Acad Sci USA 95:35973602 . 